\title{
Postharvest quality of two orange-fleshed sweet potato [Ipomoea batatas (L) Lam] cultivars as influenced by organic soil amendment treatments
}

\author{
Richard A. Atuna ${ }^{1}$ (D) | Wilberforce O. Aduguba ${ }^{2}$ | Abdul-Razak Alhassan ${ }^{2}$ | \\ Issah A. Abukari ${ }^{3}$ | Tawanda Muzhingi ${ }^{4}$ (D) | Daniel Mbongo ${ }^{4}$ | Francis K. Amagloh ${ }^{1}$
}

${ }^{1}$ Department of Food Science and Technology, University for Development Studies, Tamale, Ghana

${ }^{2}$ Department of Biotechnology and Molecular Biology, University for Development Studies, Tamale, Ghana

${ }^{3}$ Council for Scientific and Industrial Research-Savanna Agricultural Research Institute, Tamale, Ghana

${ }^{4}$ International Potato Center (CIP), Food and Nutritional Evaluation Laboratory, BecA Hub ILRI, Nairobi, Kenya

\section{Correspondence}

Francis K. Amagloh, Department of Food Science and Technology, University for Development Studies, Tamale, Ghana.

Email: fkamagloh@uds.edu.gh

Funding information

Bill and Melinda Gates Foundation, Grant/ Award Number: OPP1019987; International Potato Center, SASHA II project

\begin{abstract}
Two orange-fleshed sweet potato cultivars: Apomuden and "Nane" were grown on cow dung-, chicken manure-, compost-amended soils, and untreated soil. Apomuden is a variety, while "Nane" is being evaluated to be released in Ghana. The storage roots (SRs) were harvested at 3 months, cured by heaping the SRs and covering with the sweet potato foliage for 7 days in the field. The cured SRs were kept in an evaporative cool chamber to study the effect of soil amendment treatments on weight loss, rot, some nutrient composition, and sensory attributes. Boiled SRs were assessed by 70 untrained panelists after 7 weeks of storage based on the following: general appearance, sweetness, finger-feel firmness, and overall acceptability using a 5-point hedonic scale $(1$ = dislike extremely to 5 = like extremely). Percent rot for "Nane" showed a linear trend, while that of Apomuden was nonlinear. Both cultivars showed similar trends in terms of cumulative weight loss with "Nane" recording lower weight loss compared with Apomuden. A significant $(p<0.001 ; r=0.71)$ strong positive correlation was observed between weight loss and rots. "Nane" had higher dry matter (37.15\% vs. $30.19 \% ; p<0.001$, respectively) and starch content $(59.16 \%$ vs. $51.86 \%$; $p<0.001$, respectively) than Apomuden. Stored SRs grown on chicken manureamended soil recorded the highest protein $(6.41 \% ; p<0.001)$ and $\beta$-carotene (16.64 mg/100 g; $p<0.001)$ content than the other treatments. There was a $35 \%$ decline in $\beta$-carotene for Apomuden, while "Nane" increased by $24 \%$ at the end of the 7-week storage. "Nane," the cultivar with high dry matter content had good storage properties than Apomuden. Stored SRs cultivated on soils amended with chicken manure had higher $\beta$-carotene and protein content. All sensory attributes ranged from 3.35 to 3.68 indicating a good consumer preference for both cultivars irrespective of the soil amendment treatment applied.
\end{abstract}

\section{KEYWORDS}

cooling, evaporative, organic, poultry, storage, sweet potato 


\section{1 | INTRODUCTION}

Sweet potato (Ipomoea batatas (L) Lam) is an important food security crop in many developing countries including Ghana (Essilfie, OfosuAnim, Dapaah, Norman, \& Blay, 2015). Major production of the crop is carried out in developing countries (Crissman et al., 2007). However, over the years, there has been a decline in sweet potato yield due to the inherent poor soils in these low-income countries (Sowley, Neindow, \& Abubakari, 2015). Sweet potato is a hardy crop and can strive on marginal soils (Nedunchezhiyan \& Ray, 2010). Notwithstanding its hardy nature, it still requires some important nutrients to realize its full production potential. Inorganic fertilizers may enhance good yields (Ali, Costa, Abedin, Sayed, \& Basak, 2009), but farmers in low-income countries cannot afford the costly inorganic fertilizers. Although not the focus of this study, it has been reported that the shelf life of root and tuber crops was compromised with the application of inorganic fertilizers (Biruk-Masrie, NigussieDechassa, Abebie, Alemayehu, \& Tana, 2014; Eze \& Orkwo, 2010). For example, increased application of urea in carrot resulted in increased rots and visible molds (Hailu, Seyoum, \& Dechassa, 2008).

Therefore, the search for cheaper soil amendments such as organic fertilizers to improve the soil fertility has become more important. Organic fertilizers improve the physical, chemical, and biological characteristics of the soil thereby increasing productivity for improved income, food, and nutrition security (Bhaskaran \& Krishna, 2009; Essilfie et al., 2015; Gibberson, Joshua, Ato, Justice, $\&$ Paul, 2016). As research efforts are directed toward improving soil fertility for increased yields, it is important to consider the effect of the organic fertilizer on the storage and nutritional qualities of storage roots (SRs). For instance, soils amended with different organic fertilizers were found to have an influence on the storage qualities of two sweet potato varieties in Ghana (Essilfie, 2015). The protein content in plants depends largely on the availability of nitrogen $(\mathrm{N})$ at planting, $\mathrm{N}$ released during the growing season, through mineralization of soil organic matter, and $\mathrm{N}$ applied as organic or inorganic fertilizer (Wang, Li, \& Malhi, 2008).

Sweet potato generally has a short shelf life that is reported to be 7-10 days under tropical market conditions (Rees et al., 2003). This may vary depending on the cultivar and storage conditions (Ray, Ravi, Hegde, Rao, \& Tomlins, 2010). However, under controlled temperature $\left(13-15^{\circ} \mathrm{C}\right)$ and relative humidity $(90 \%)$, sweet potato RSs can be stored up to one year (Woolfe, 1992). Although refrigeration is a common storage method, sweet potato and some fruits cannot be stored longer due to their susceptibility to chilling injury (Liberty, Okonkwo, \& Echiegu, 2013; Olosunde, Igbeka, \& Olurin, 2009). Furthermore, maintaining suitable temperature and relative humidity in tropical low-income countries may be expensive and unsustainable (Lal Basediya, Samuel, \& Beera, 2013). The current farmers' village-level storage methods are mostly unsatisfactory (Hayma, 2003) leading to average losses of $20-25 \%$ in sweet potato (Jenkins, 1982). In a recent study, the household-level sandbox storage method was recommended for being able to extend the shelf life of storage roots by 2 months (Abidin et al., 2016). However, its commercial potential for improved income is limited because of the volume of SRs it can hold.

Fruits and vegetables have long been preserved using evaporative cooling system. When dry air passes over a wet surface, it causes evaporative cooling; the degree and efficiency of cooling depend on the evaporation rate and humidity of the ambient air (Liberty, Ugwuisuwu, Pukuma, \& Odo, 2013). This passive cooling method differs from refrigeration or normal air conditioning because there is no external energy source. Evaporative cooling has a great potential in tropical countries like Ghana, because the harmattan season (November-March) that is characterized by warm dry air and low relative humidity (Mittal, Kataria, Das, \& Chatterjee, 2006) may bring efficient evaporative cooling effect. For instance, the shelf life of garden eggs was reported to be extended by 9 days with evaporative cooling unit (Ganesan, Balasubramanian, \& Bhavani, 2013).

In this study, the evaporative cooling system was adopted as a storage system to study the effect of organic soil amendment treatment on some compositional and sensory attributes of SRs.

\section{2 | MATERIALS AND METHODS}

\section{1 | Study location and experimental design}

The cultivation and curing of sweet potato were carried out in the trial fields of Council for Scientific and Industrial Research-Savanna Agricultural Research Institute (CSIR-SARI), Nyankpala ( $9^{\circ} 24^{\prime} \mathrm{N}$, $0^{\circ} 59^{\prime} \mathrm{W}, 183 \mathrm{~m}$ above sea level), Ghana. The storage experiment was also carried out at the University for Development Studies, Nyankpala campus, Tamale ( $9^{\circ} 25^{\prime} \mathrm{N}, 0^{\circ} 59^{\prime} \mathrm{W}, 189 \mathrm{~m}$ ). Both locations fall within the Guinea Savannah Agroecological Zone of Ghana.

The experimental design used was randomized complete block design arranged in a $2 \times 4$ factorial, thus two orange-fleshed cultivars: Apomuden and "Nane"; four soil amendment treatments: Chicken manure, cow dung, compost, and untreated as control. The application rates for the organic manure were 10/tha as recommended elsewhere (Edison et al., 2009). The two orange-fleshed sweet potato cultivars were Apomuden, a released variety in Ghana with a long irregular shape and a purple-red skin color (Tumwegamire et al., 2014), while "Nane" (long oblong shape and brownish-orange skin color), a farmer cultivar currently undergoing evaluation for release in Ghana. Both cultivars were grown to optimum maturity (3 months) before harvest.

\subsection{Construction of zero energy cool chamber (ZECC) and storage}

A square shape platform measuring $3 \times 3 \mathrm{~m}$ was made with cement bricks of dimension $24 \times 14 \times 7.5 \mathrm{~cm}$. Over this platform, a double wall was erected to the height of $52 \mathrm{~cm}$ leaving a gap of $10 \mathrm{~cm}$ and wet coarse river sand was then filled in the $10-\mathrm{cm}$ gap between the walls (Figure 1a). Wire gauze and locally woven thatch cover as well as jute sack were used as top covers of the chamber. Construction of the ZECC was carried out as outlined in Roy and Khurdiya (1983). 

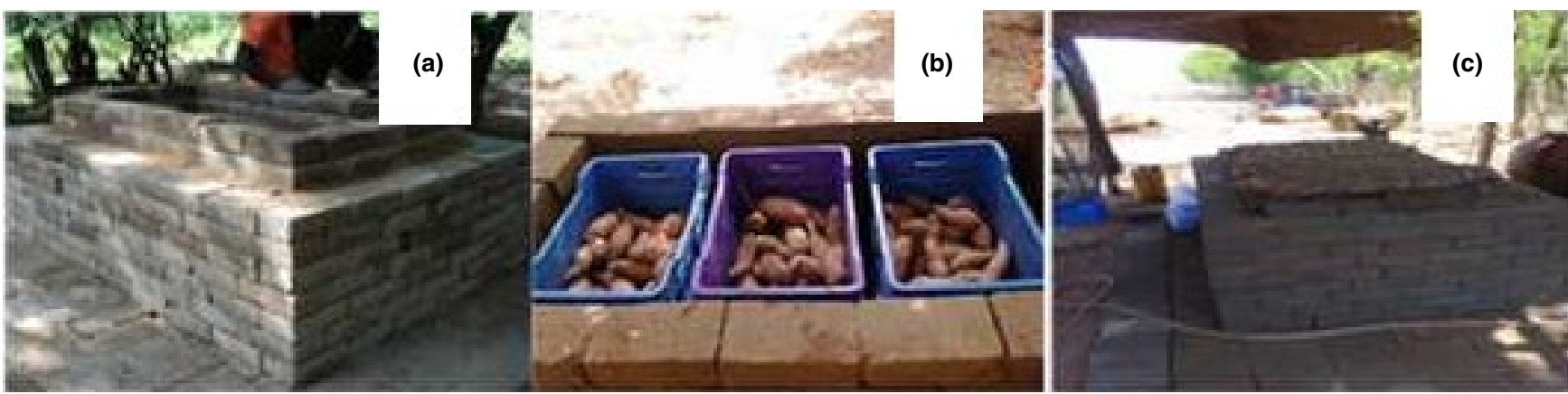

FIGURE 1 SRs in an evaporative cool chamber

After SRs were carefully harvested, sorted, and field-piled cured for seven days, they were carefully transported to the storage site ensuring they were not bruised during the transportation. Further sorting was carried out to ensure only good quality SRs were stored. Fifteen kilograms $(15 \mathrm{~kg}$ ) of each cultivar from the four soil amendment treatments was weighed into plastic crates $(51 \times 32 \times 30 \mathrm{~cm})$ in triplicates. The crates filled with SRs were then randomly stored in the cool chambers (Figure 1b), ensuring each cool chamber contained six crates with two of them stacked on each other. The top covers were then used to cover the ZECC (Figure 1c).

Throughout the experimental period, the sand between the walls, bricks, and top covers of the chamber was kept moist with $100 \mathrm{~L}$ of water per day as recommended by Ganesan et al. (2013). The internal temperature and relative humidity of the ZECC ranged $21.1-24.9^{\circ} \mathrm{C}$ and $88.8-98.7 \%$, respectively, over the storage period.

\section{3 | Weight loss, weevil damage, sprout, and rot}

The weight of SRs in each crate was taken and recorded weekly. Weight loss was determined by the difference between the initial weight and final weight expressed as a percentage.

SRs were examined weekly for the presence of sweet potato weevil (Cylas spp.). The number of SRs damaged was divided by the total number of SRs in the crate and expressed as a percentage to obtain percent weevil damage.

The weekly number of spouted SRs was also determined and divided by the total SRs count in the crate and multiplied by 100 for percent sprouts.

SRs were assessed weekly for the incidence of rot. The number of rotten SRs was taken and recorded. The percent rot was determined as the number of rotten SRs divided by the total SR count in the crate and expressed as a percentage.

\section{4 | Compositional analysis}

Freshly harvested and field-piled cured SRs were taken for compositional analysis using the near-infrared reflectance spectroscopy method. Samples were also taken 1 and 2 months after storage for the compositional analysis.
At least three SRs (small, medium, and big) were purposively selected for the quality analysis. The selected SRs were washed, peeled, and washed again with deionized water before quartering longitudinally and slicing it into pieces. The sliced samples about $50 \mathrm{~g}$ were placed into zip-locked bags before they were put into a freezer. The samples were then freeze-dried for $72 \mathrm{hr}$ using the TK-118 Vacuum Freeze Dryer (True Ten Industrial Company Limited Taichung, Taiwan). The freeze-dried samples were crushed into small size and then milled into flour using a stainless steel mill (3383-L70, Thomas Scientific, Dayton Electric Manufacturing Company Limited, Niles, IL, USA) and sieved through a 60-mm mesh screen. The flour from the mill was collected using labeled zip-locked bags and duly sealed until removed for analysis. About $5 \mathrm{~g}$ of flour of each sample was put into the cuvette and scanned for all the compositions using XDS Rapid Content Analyser (Hoganae, Sweden). The parameters analyzed include dry matter, glucose, fructose, sucrose, and starch. All determinations were assayed in triplicates.

The $\beta$-carotene analysis was performed at the Food and Nutrition Laboratory, ILRI, Kenya. All extraction of carotenoids from OFSP fresh roots was carried out under yellow-golden lights in FANEL. Extraction and chromatographic separation of carotenoids were performed according to the previously published methods with some modifications (Riso \& Porrini, 1997). Extraction of carotenoids from OFSP fresh roots was performed using direct extraction with methanol and tetrahydrofuran (THF) as published previously (Muzhingi, Yeum, Qin, \& Tang, 2008). Briefly, $1 \mathrm{~g}$ of OFSP fresh root grates was extracted for carotenoids by incubation with $10 \mathrm{ml}$ methanol for $10 \mathrm{~min}$ at $85^{\circ} \mathrm{C}$ and vortexed for $1 \mathrm{~min}$ at $5 \mathrm{~min}$ intervals. Afterward, the mixture was homogenized for $30 \mathrm{~s}$ in an ice bath. The mixture was centrifuged at 800 -x $\mathrm{g}$ for $5 \mathrm{~min}$. The methanol layer was transferred into a $50-\mathrm{ml}$ volumetric flask, and the extraction was repeated four times with $10 \mathrm{ml}$ of THF, followed by vortexing and centrifugation. The THF layers were combined with the methanol layer and the volume brought up to $50 \mathrm{ml}$. One $\mathrm{ml}$ of the extract was dried under a gentle stream of nitrogen using an N-Evap System (Organomation, Berlin, MA). The dried test tube contents were reconstituted in $1 \mathrm{ml}$ of ethanol, sonicated for $1 \mathrm{~min}$, vortexed for $30 \mathrm{~s}$, and transferred into a 2-ml HPLC vial. Then, $50 \mu \mathrm{l}$ was injected into the HPLC system for analysis. The HPLC systems consisted of a Shimadzu CBM -20A Prominence Bus Module, SPD -M20A Prominence Photo Diode Array (PDA), DGU 20A5R 
Prominence Degasser Module, SIL 30AC Nexera Autosampler, two Nexera X2 LC 30AD pumps, a YMC Carotenoid S-3 $\mu \mathrm{m}, 150 \times 3.0 \mathrm{~mm}$ I.D column, and Shimadzu LabSolutions data management software. The HPLC mobile phase was methanol: methyl-tert-butyl ether: water (83:15:2, v/v/v, with $1.5 \%$ ammonium acetate in the water, solvent $A$ ) and methanol: methyl-tert-butyl ether: water (8:90:2, v/v/v, with $1 \%$ ammonium acetate in the water, solvent $\mathrm{B})$. The gradient procedure at a flow rate of $1 \mathrm{ml} / \mathrm{min}$ was as follows: 1) $90 \%$ solvent $A$ and $10 \%$ solvent $B$ for 5 min; 2) a 12 -min linear gradient to $55 \%$ solvent $A$; 3 ) a 12 -min linear gradient to $95 \%$ solvent B; 4) a 5-min hold at $95 \%$ solvent $B$; and 5) a 2 -min gradient back to $90 \%$ solvent $A$ and $10 \%$ solvent B. Carotenoids were monitored at UV maximum absorption of $450 \mathrm{~nm}$ and DAD spectral data from 250 to $550 \mathrm{~nm}$ were stored to examine spectrum peaks for carotenoids. Carotenoids were quantified by determining peak areas in the HPLC chromatograms calibrated against known amounts of standards.

\section{5 | Samples preparation for sensory evaluation}

Wholesome SRs about $1 \mathrm{~kg}$ of both Apomuden and "Nane" from the two homestead storage methods were selected into labeled net bags. The SRs were then washed and wet cooked for 20 min to become soft. The peels of the cooked SRs were removed with a knife and sliced to thumb sizes for the consumer preference test. Three figure-coded disposable plates were used to serve the samples for scoring by the panelist. The consumer acceptability test took place at a dining room of Alimento Catering Service, University for Development Studies, Nyankpala.

\subsection{Consumer preference test}

A sensory analysis was conducted using sensory ballot. A fivepoint hedonic scale, 1 = extremely dislike, 2 =dislike, $3=$ neither like nor dislike, 4 = like, and 5 = like extremely, was used to assess the sensory qualities of boiled SRs. The boiled SRs were evaluated by 70 (female $=14$, male $=56$ ) untrained panelists from the University for Development Studies. The sensory attributes

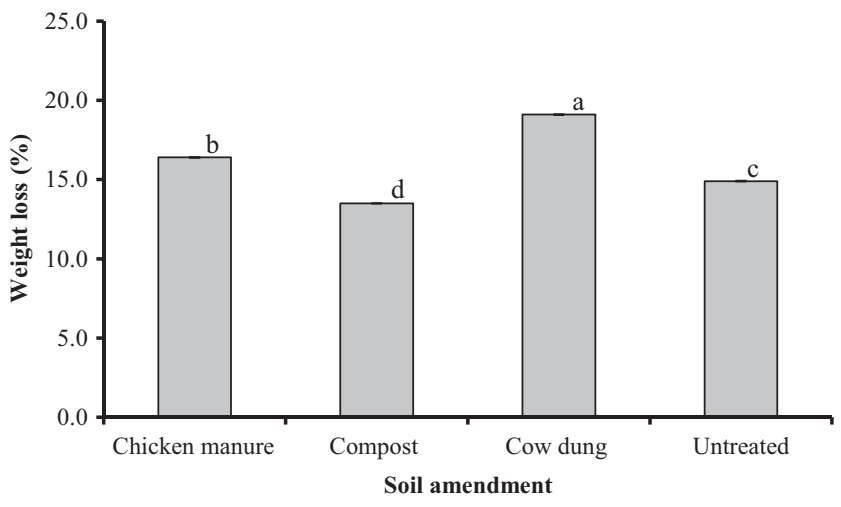

FIGURE 2 Effect of soil amendment on sweet potato SRs during a 7-week storage period in Nyankpala, 2016. Bar values (Means \pm SEM, $n=3$ ). Means with the same letters are not significantly different $(p>0.05)$ evaluated were General appearance; sweetness (sugariness); Fingerfeel firmness; and Overall acceptability. The attribute sweetness was explained to panelist to mean desired taste as described by other researchers (Kapinga, Jeremiah, Rwiza, \& Rees, 2003). Consumers rinsed their mouth with water before and in-between samples.

\section{7 | Statistical analysis}

The physical SRs quality data, rot, sprout, and weight loss, were subjected to a two-way analysis of variance in general linear model using SAS. The rot and sprout data were square root transformed with excel $(=\mathrm{SQRT}(\mathrm{A} 2+0.5))$ and untransformed/detransformed $\left(=\left(B 2^{*} B 2\right)-0.5\right)$ after analysis. The weight loss data were Arcsine square root transformed (=ASIN(SQRT(D2))) and untransformed/ detransformed $\left(=(\mathrm{SIN}(\mathrm{E} 2))^{*}(\mathrm{SIN}(\mathrm{E} 2))\right)$ after analysis.

A simple correlation and regression analysis were performed to establish the relationship between weight loss and rot. Moreover, a paired sample t test was used to analyze compositional quality data before and after storage in Minitab v16.2.4 (Minitab ${ }^{\circledR}$ Inc. USA). The Tukey's studentized range test was used to determine which of the means was significant at $(p<0.05)$. The statistical analysis for the sensory test was performed using Microsoft ${ }^{\circledR}$ Excel 2010/ XLSTATC-Pro (version 2016.02; Addinsoft, Inc., Brooklyn, NY, USA). The Mann-Whitney test was used to analyze treatments cultivar and gender. Kruskal-Wallis nonparametric test procedure was employed to analyze the effect of the soil amendment treatment. Multiple pairwise comparisons were made using the Steel-DwassCritchlow-Fligner procedure/two-tailed test when $p<0.05$

\section{RESULTS}

\section{1 | Physical storage root quality}

Regardless of the cultivar type, SRs produced from the various soil amendment treatments were significantly $(p<0.04)$ different with regards to percent weight loss (Figure 2). SRs produced from compostamended soil recorded the least weight loss over the storage period, about 1.1, 1.2, and 1.4 times, respectively, lower than SRs grown from untreated, chicken manure-amended, and cow dung-amended soils.

Apomuden and "Nane" were significantly $(p<0.05)$ different in the various soil amendment treatment (Figure 3). For all the soil amendment treatment, percent rot was higher in Apomuden than Nane. SRs of Nane grown from chicken manure-amended soil recorded the least percent rot compared with cow dung-amended, compost-amended and the no amendment.

The data (Figure 4) represent percent rot (A), sprouts (B), and weight loss (C) of SRs over 7-week storage period in an evaporative cool chamber. Percent rot for "Nane" followed a linear trend as storage progressed (Figure 3a). About $100 \%$ of the variation in percent rot is explained by storage period. However, percent rot in Apomuden was nonlinear (cubic) with about $95 \%$ of the variation in percent rot being as a result of its association with length of storage. 


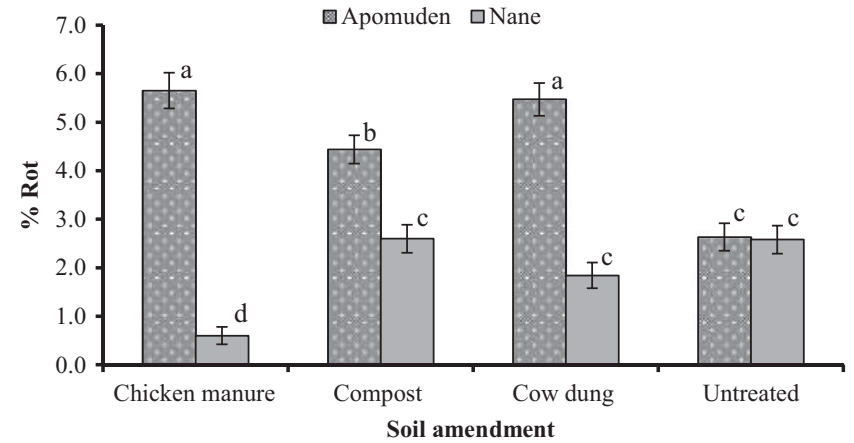

FIGURE 3 Effect of soil amendment on sweet potato SRs rot during a 7-week storage period in Nyankpala, 2016. Bar values (Means \pm SEM, $n=3$ ). Means with the same letters are not significantly different $(p>0.05)$

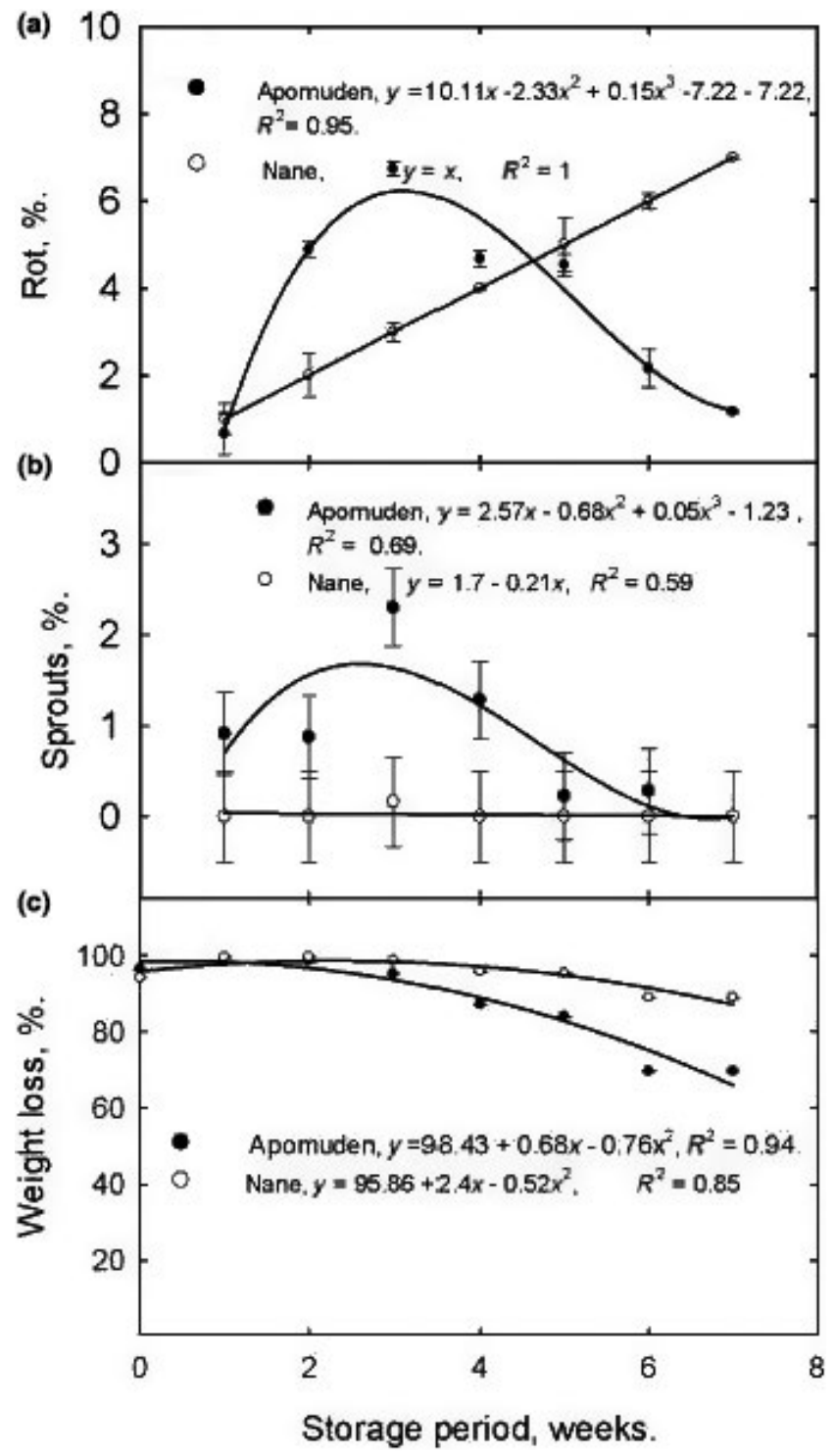

FIG URE 4 Sweet potato SRs rots (a), sprouts (b), and weight loss (c) over a 7-week storage period in Nyankpala, 2016. Values are means \pm SEM, $n=3$
Percent sprout (Figure 4b) in "Nane" was stable over the storage period. However, a unit change in storage time resulted in $0.21 \%$ decline in percent sprout with about $59 \%$ of the model being explained. On the contrary, a nonlinear (cubic) relationship was observed between percent sprout and storage period. The cumulative weight loss in both Apomuden and "Nane" followed a similar trend with "Nane" recording lower weight loss compared with Apomuden over the storage period (Figure 4c). Percent weight loss and rots were observed to have a significantly $(p<0.001 ; r=0.71)$ strong positive linear relationship. This implies that, as sweet potato losses weight through transpiration and respiration, there is a high possibility of decay in those SRs.

\section{2 | Compositional quality}

Soil amendment treatment significantly $(p<0.05)$ affected all SRs compositional qualities except for dry matter and starch. SRs grown from compost-amended soil recorded the highest fructose; glucose, and sucrose content (Table 1) compared with the other soil amendment treatments. Apomuden and "Nane" differed significantly $(p<0.05)$ in all SRs compositional qualities (Table 1). The dry matter content of "Nane" (37.15\%) was about 1.2 times higher than Apomuden (30.19\%). As expected, the fructose, glucose, and sucrose contents were about 2.4, 2.1, and 1.2 times, respectively, lower in "Nane" compared with Apomuden (Table 1).

The combined effect of cultivar and soil amendment treatment showed no significant differences $(p>0.05)$ for all compositional qualities assessed except for $\beta$-carotene that Apomuden grown on chicken manure-amended soil had a significantly higher $(19.13 \mathrm{mg} / 100 \mathrm{~g} ; p<0.001)$ compared with the other treatment combinations (Table 2). Irrespective of the cultivar, sweet potato grown on chicken manure-amended soils had higher $\beta$-carotene content (14.14-19.13 mg/100 g) compared with the other soil amendment treatments.

The data from Table 3 showed no significant $(p>0.05)$ effect of storage on the dry matter content of the SRs. However, the fructose and glucose contents of Apomuden were significantly $(p<0.05)$ influenced during storage, while the sucrose and starch contents of "Nane" were also significantly $(p<0.05)$ affected during storage. The results further revealed that the starch content of Nane declined, while there was an increase in sucrose content during storage.

The $\beta$-carotene content of Apomuden and "Nane" before and after storage is presented in Figure 5. Apomuden recorded a significantly $(p<0.001)$ higher $\beta$-carotene content relative to "Nane" before storage. However, the $\beta$-carotene of Apomuden significantly $(p<0.001)$ declined; about 35\% after storage for 7 weeks. However, the $\beta$-carotene content in "Nane" increased by $24 \%$ after 7 -week storage.

\section{3 | Sensory quality}

All sensory attributes had a sensory score above 3 , an indication of good consumer preference. With the exception of general 
TAB LE 1 Main effects of soil amendment treatments and cultivar on SR compositional quality on dry matter basis, Nyankpala, 2016

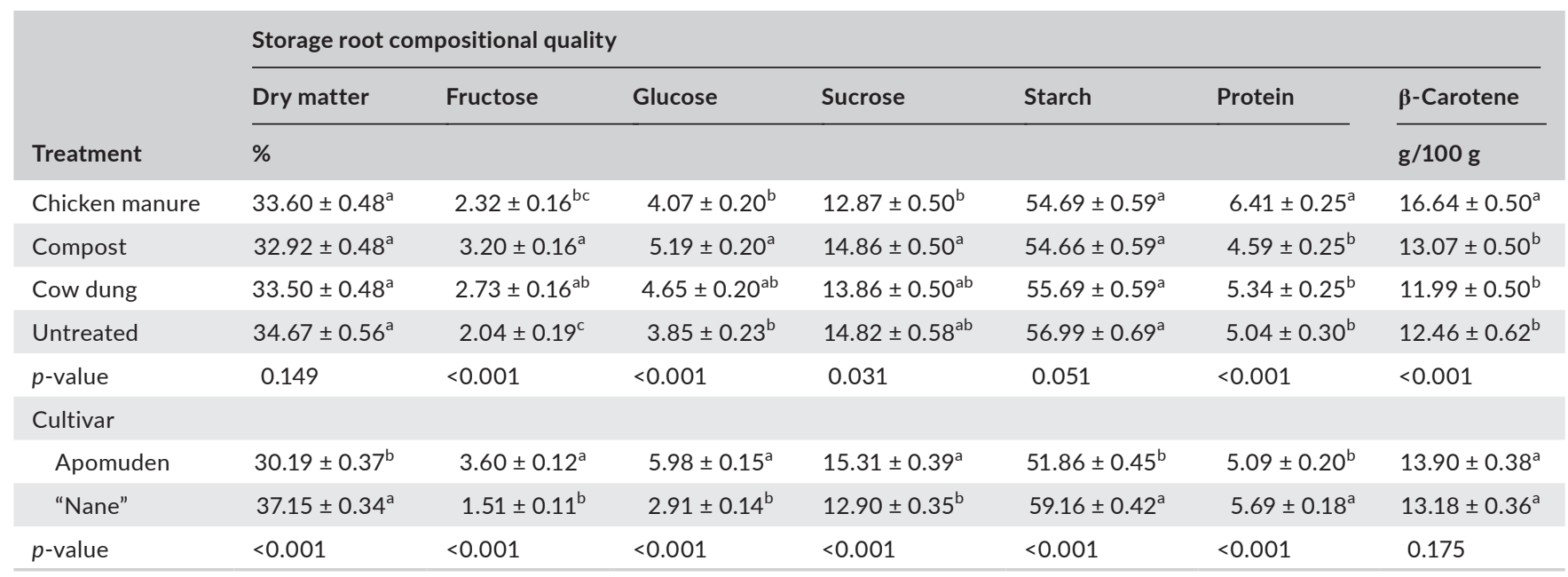

Note. Values represent least square means $\pm \mathrm{SEM}, n=3$. Least square means in the same category in a column with different letters are significantly different $(p<0.05)$.

TAB LE 2 Combined effects of soil amendment treatment and cultivar on storage root compositional quality on dry matter basis, Nyankpala, in 2016

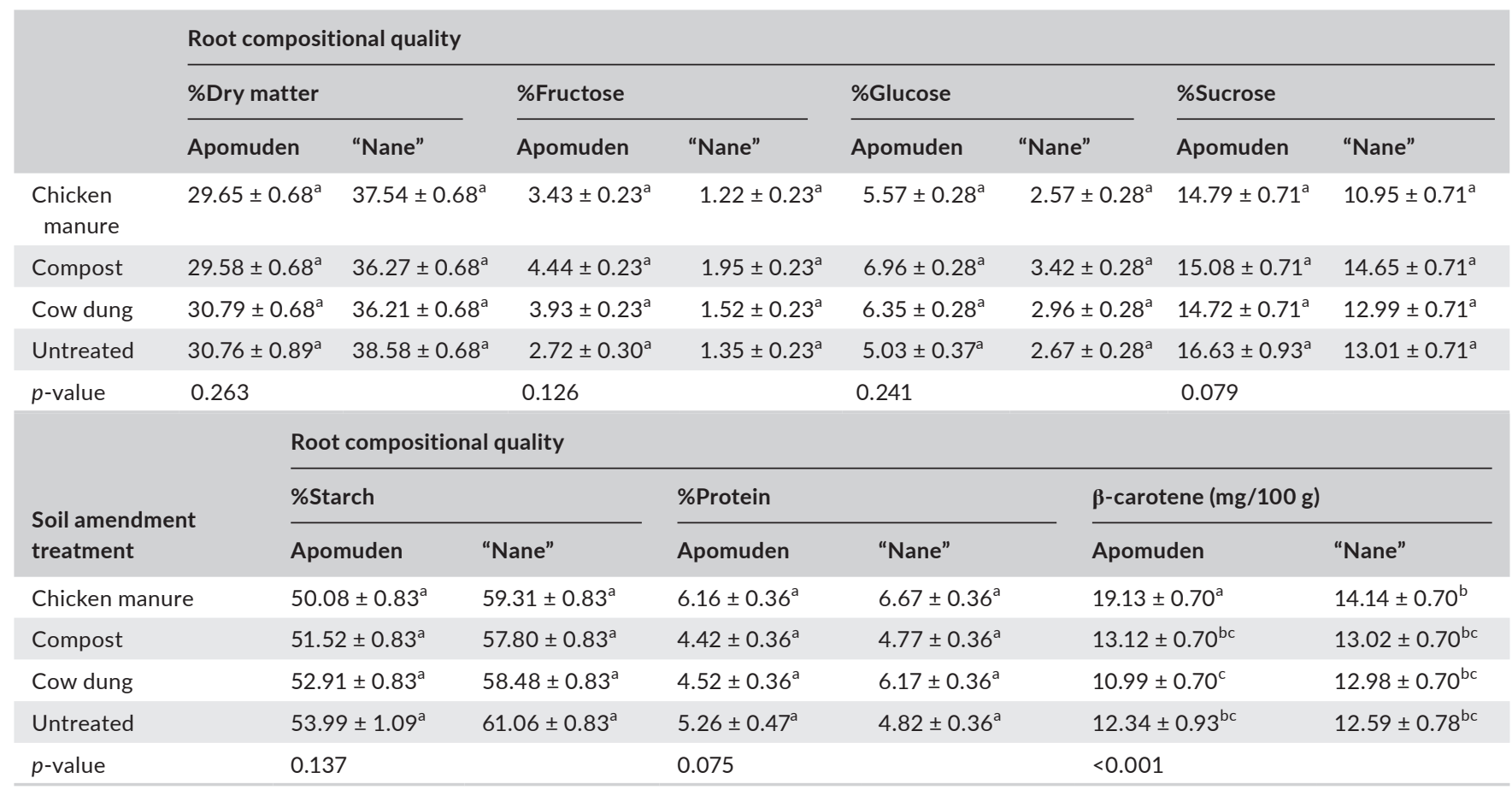

Note. Values represent the least square means of three samples $\pm \mathrm{SEM}, n=3$. Least square means in the same category in a column with different letters are significantly different $(p<0.05)$.

appearance, the data showed that soil amendment treatment had no significant influence $(p>0.05)$ on all sensory attributes except for general appearance that the untreated (control) had a significantly high sensory score $(p=0.017)$ compared to the other soil treatments (Table 4).

Generally, there was no significant difference $(p>0.05)$ between Apomuden and "Nane" for all sensory attributes evaluated. However, "Nane" had a higher score on general appearance and finger-feel firmness. On the other hand, Apomuden had a high sensory score in terms of sweetness and overall acceptability relative to "Nane." Both male and females similarly $(p>0.05)$ ranked all sensory attributes assessed.

\section{DISCUSSION}

The significantly difference in weight loss of SRs grown from the various soil amendment treatment could be attributed to the difference 
TAB LE 3 Changes in storage root compositional quality on dry matter basis with storage time, Nyankpala, 2016

\begin{tabular}{|c|c|c|c|c|c|c|c|}
\hline Cultivar & Storage time & \multicolumn{6}{|c|}{ Root compositional quality } \\
\hline Apomuden & $\begin{array}{l}7 \text { Weeks After } \\
\text { storage }\end{array}$ & $31.03 \pm 0.56 a$ & $2.59 \pm 0.16 b$ & $4.62 \pm 0.20 b$ & $15.71 \pm 0.50 a$ & $51.92 \pm 0.59 c$ & $5.48 \pm 0.25 a$ \\
\hline "Nane" & $\begin{array}{l}7 \text { Weeks After } \\
\text { storage }\end{array}$ & $37.31 \pm 0.48 a$ & $1.39 \pm 0.16 c$ & $3.00 \pm 0.20 c$ & $15.63 \pm 0.50 a$ & $56.16 \pm 0.59 b$ & $5.82 \pm 0.25 a$ \\
\hline$p$-value & & 0.188 & $<0.001$ & $<0.001$ & $<0.001$ & $<0.001$ & 0.497 \\
\hline
\end{tabular}

Note. Values represent the least square means of three samples $\pm \mathrm{SEM}, n=3$. Least square means in the same category in a column with different letters are significantly different $(p<0.05)$.

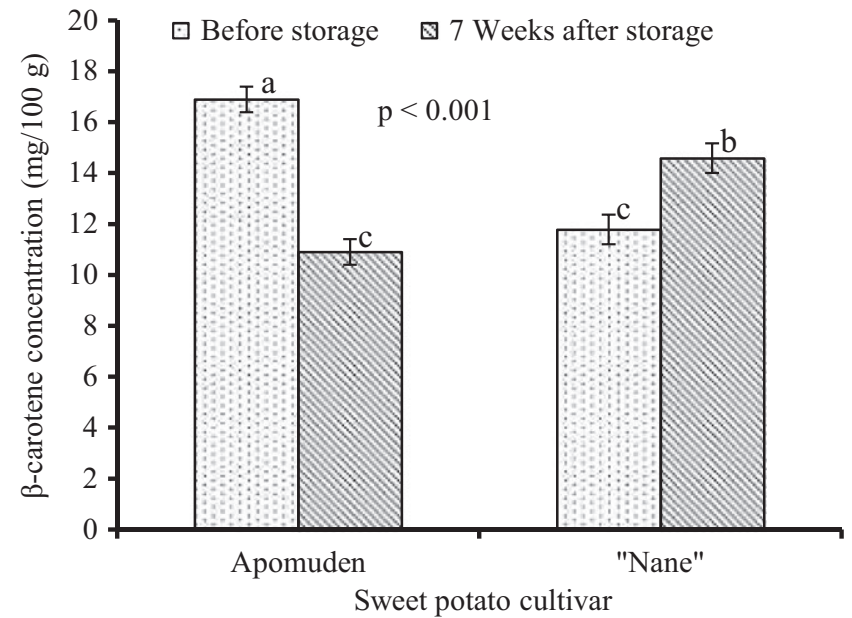

FIGURE 5 Changes in $\beta$-carotene concentration on dry matter basis of sweet potato cultivars with storage time, Nyankpala, 2016. Bar values (least square means $\pm \mathrm{SEM}, n=3$ ). Least square means with the same letters are not significantly different $(p>0.05)$

in their nutrient composition especially that of $\mathrm{N}$ and $\mathrm{K}$ as increased preharvest application of $\mathrm{N}$ and $\mathrm{K}$ resulted in increased weight loss in potato tubers during storage (Kolbe, Müller, Olteanu, \& Gorea, 1995). In another study, increased $\mathrm{N}$ application related directly with weight loss in the SRs of sweet potato during storage (Weston \& Barth, 1997).

"Nane" recorded significantly lower rot in SRs grown from chicken manure-amended and cow dung-amended soil compared with untreated and compost-amended soil. The finding agrees with the findings of Sowley et al. (2015) who reported that $80 \%$ of rot occurred in SRs grown in unfertilized soil and stored compared with poultry manure and inorganic fertilizer. However, Apomuden produced from the untreated had significantly lower rots compared with those produced from chicken manure-amended, cow dungamended, and compost-amended soils. Differences in cultivars may account for this observation.

Apomuden and "Nane" differed significantly with regards to percent rot over the storage period, and this is supported by previous studies that showed variability in decay among sweet potato cultivars (Cooley, Kushman, \& Smart, 1954). The short sprouts observed during the storage of SRs in the evaporative chamber in this study could be an indication of good quality SRs as Van Oirschot et al. (2007) reported that sound or healthy SRs sprout readily. Furthermore, it is not unusual to find short sprouts (less than onefourth inch) during curing and storage (Chakraborty, Roychowdhury, Chakraborty, Chakravorty, \& Ghosh, 2017; Edmunds et al., 2008). These short sprouts are usually broken off before SRs are sold. The results on percent weight loss are in conformity with results of earlier studies that showed that sweet potato cultivars differed widely in physiological weight loss ability (Chattopadhyay, Chakraborty, Kumar, Nanda, \& Sen, 2006). For instance, cultivars with high dry matter content have low respiration rate compared with those with low dry matter content (Hirose, Data, \& Quevedo, 1984; Ravi, Aked, \& Balagopalan, 1996). The high moisture loss in Apomuden, the cultivar with low dry matter content, could be attributed to high respiration resulting in poor storage compared with "Nane," the cultivar with relatively high dry matter content. The findings by Karuri and Hagenimana (1995) support the current findings as Apomuden with initially high moisture content, recorded higher degree of rot in all soil amendment treatment.

Application of organic manure generally increased the concentration of reducing sugars in sweet potato SRs. Similar findings were made in the roots of carrot by Hailu et al. (2008). However, in this study, some organic amendment resulted in higher accumulation of reducing sugar in the SRs than others. The variation in reducing sugar among the soil amendment treatment could be ascribed to differences in $\mathrm{N}$ source.

The high protein and $\beta$-carotene contents of SRs grown on chicken manure-treated soil corroborate previous works that showed that the application of $\mathrm{N}$ and $\mathrm{P}$ increased the protein and carotene content of tubers during bulking (Ezell \& Wilcox, 1952; Wang et al., 2008). The high levels of $N($ Total $N=1.889 \%$ ) and $P$ (Bray I $P=9788.5 \mathrm{ppm}$ ) in the chicken manure-amended soils could be attributed to chicken manure-amended treatments having the highest protein and $\beta$-carotene contents. The biosynthesis of protein 
TA B LE 4 Consumer acceptability test of boiled SRs after 7 weeks storage in ZECC at Nyankpala, 2016

\begin{tabular}{|c|c|c|c|c|}
\hline \multirow[b]{2}{*}{ Soil amendment* } & \multicolumn{4}{|l|}{ Sensory attributes } \\
\hline & General appearance & Finger-feel firmness & Sweetness & Overall acceptability \\
\hline Chicken Manure & $238.53^{a}$ & $247.03^{a}$ & $256.64^{a}$ & $251.61^{a}$ \\
\hline Compost & $240.76^{a}$ & $244.14^{a}$ & $234.84^{a}$ & $240.70^{a}$ \\
\hline Untreated & $308.77^{b}$ & $232.47^{a}$ & $257.83^{a}$ & $249.66^{a}$ \\
\hline Cow dung & $226.16^{a}$ & $251.71^{a}$ & $239.02^{a}$ & $242.17^{a}$ \\
\hline$p$-value & $<0.001$ & 0.804 & 0.437 & 0.890 \\
\hline \multicolumn{5}{|l|}{ Cultivar $^{\dagger}$} \\
\hline Apomuden & $3.35 \pm 1.04^{b}$ & $3.46 \pm 1.07^{a}$ & $3.64 \pm 1.07^{a}$ & $3.68 \pm 0.97^{a}$ \\
\hline "Nane" & $3.65 \pm 1.12^{a}$ & $3.53 \pm 1.10^{a}$ & $3.54 \pm 1.11^{a}$ & $3.65 \pm 1.08^{a}$ \\
\hline$p$-value & 0.001 & 0.443 & 0.339 & 0.978 \\
\hline \multicolumn{5}{|l|}{$\operatorname{Sex}^{\dagger}$} \\
\hline Male $(n=56)$ & $3.51 \pm 1.11^{a}$ & $3.48 \pm 1.08^{a}$ & $3.59 \pm 1.11^{a}$ & $3.67 \pm 1.02^{a}$ \\
\hline Female $(n=14)$ & $3.59 \pm 1.00^{a}$ & $3.58 \pm 1.08^{a}$ & $3.53 \pm 1.11^{a}$ & $3.63 \pm 1.10^{a}$ \\
\hline$p$-value & 0.455 & 0.406 & 0.597 & 0.755 \\
\hline
\end{tabular}

Notes. Means/rank means in the same column with the same letters are not significantly different $(p>0.05)$.

*Values are rank means. ${ }^{\dagger}$ Values represent the means of three samples \pm SD.

and carotenoids in higher plants has been reported to be closely linked with the availability of $N$ (Weston \& Barth, 1997).

The varying $\beta$-carotene and sucrose content between Apomuden and "Nane" could be related to cultivar difference and presents important knowledge that is relevant during processing.

Varietal difference is a major factor that determines changes in carotenoid content during storage (Ezell \& Wilcox, 1952) and could be attributed to the observed findings in the current study. Thus, some sweet potato genotypes are more sensitive to storage temperature than others.

Although not significant, both fructose and glucose content of Apomuden and "Nane declined with storage and this finding lends support to (Lewthwaite, Sutton, \& Triggs, 1997) who reported a decline in fructose and glucose content of SRs during storage. The finding, however, contradicts those of (Adu-Kwarteng et al., 2014) who found a general increase in the concentration of both fructose and glucose after storage. The differences in findings could be attributed to the fact that, in the current study, maturity at the time of harvest was not taken into account unlike the previous study. The increase in "Nane sucrose during storage is in conformity with earlier findings (Adu-Kwarteng et al., 2014; Lewthwaite et al., 1997) that showed that the sucrose content of some sweet potato cultivars generally increased with storage.

Varietal differences may account for the differences in the dry matter content as similar findings were reported elsewhere (Essilfie, 2015). The starch content of sweet potato SRs generally falls during storage, but varies among cultivars. The variation in starch content with storage is attributed to the conversion of starch to sugar (Degras, 2003). Probably, the conversion of starch into sugar was high in "Nane" resulting in rapid decline in starch content with storage compared with Apomuden.
The findings on the influence of soil amendment treatment on the sensory quality of SRs agree with Essilfie (2015) who reported that the sensory characteristics of boiled roots of two sweet potato cultivars were not remarkably affected by application of organic and inorganic fertilizer either singly or in combination. "Nane" with a higher score on general appearance and finger-feel firmness may be due to its relatively high dry matter content compared to Apomuden. Firmness according to (2003) is an indicator of high dry matter content, a trait of sweet potato preferred by African consumers (Baafi et al., 2015; Tomlins et al., 2004). Sweetness (taste) among other attributes has been reported to be the main drivers consumer overall acceptability of a product (Kwach, Odhiambo, Dida, \& Gichuki, 2010). The eating quality of sweet potato has been reported to be fundamentally linked to the sugar composition (Lewthwaite et al., 1997). Thus, the higher overall acceptability score for Apomuden may be due to its higher fructose, glucose, and sucrose content than "Nane."

The fact that both male and female equally preferred both cultivars grown from either of the soil amendment treatment may suggest that both male and female consumers in Ghana will equally accept boiled SRs after they have been produced from either amended or unamended soils.

\section{5 | CONCLUSION AND RECOMMENDATION}

"Nane," the cultivar with high dry matter content, had good storage properties in evaporative cool storage than Apomuden. Stored SRs cultivated on soils amended with chicken manure had higher $\beta$ carotene and protein content in both cultivars compared with the other treatments. Therefore, chicken manure is recommended to farmers. Storage for 7 weeks resulted in $35 \%$ decline in $\beta$-carotene 
content of Apomuden and $24 \%$ increase in the $\beta$-carotene content of "Nane." All sensory attributes of the boiled SRs after evaporative cool storage for 7 weeks ranged from 3.35 to 3.68 indicating a good consumer preference for both cultivars irrespective of the soil amendment treatment applied.

\section{ACKNOWLEDGMENTS}

We acknowledge funding from International Potato Center, SASHA II project. We also thank Food and Nutrition Laboratory, ILRI, Kenya, for the $\beta$-carotene analysis.

\section{CONFLICT OF INTEREST}

The authors declare that they have no competing interest.

\section{ETHICAL REVIEW}

This study does not involve any human or animal testing.

\section{ORCID}

Richard A. Atuna iD http://orcid.org/0000-0002-4888-8710
Tawanda Muzhingi (iD http://orcid.org/0000-0002-2432-2165
Francis K. Amagloh iD http://orcid.org/0000-0001-7243-0972

\section{REFERENCES}

Abidin, P. E., Kazembe, J., Atuna, R. A., Amagloh, F. K., Asare, K., Dery, E. K., \& Carey, E. E. (2016). Sand storage, extending the shelf-life of fresh sweetpotato roots for home consumption and market sales. Journal of Food Science and Engineering, 6, 227-236.

Adu-Kwarteng, E., Sakyi-Dawson, O. E., Ayernor, S. G., Truong, V.-D., Shih, F. F., \& Daigle, K. (2014). Variability of sugars in staple-type sweet potato (Ipomoea batatas) cultivars: The effects of harvest time and storage. International Journal of Food Properties, 17(2), 410-420. https://doi.org/10.1080/10942912.2011.642439

Ali, M., Costa, D., Abedin, M., Sayed, M., \& Basak, N. (2009). Effect of fertilizer and variety on the yield of sweet potato. Bangladesh Journal of Agricultural Research, 34(3), 473-480.

Baafi, E., Manu-Aduening, J., Carey, E. E., Ofori, K., Blay, E. T., \& Gracen, V. E. (2015). Constraints and breeding priorities for increased sweetpotato utilization in Ghana. Sustainable Agriculture Research, 4(4), 1. https://doi.org/10.5539/sar.v4n4p1

Bhaskaran, U. P., \& Krishna, D. (2009). Effect of organic farming on soil fertility, yield and quality of crops in the tropics. Paper presented at the The Proceedings of the International Plant Nutrition Colloquium XVI.

Biruk-Masrie, Z., Nigussie-Dechassa, R., Abebie, B., Alemayehu, Y., \& Tana, T. (2014). Influence of combined application of inorganic $N$ and $\mathrm{P}$ fertilizers and cattle manure on quality and shelf-life of potato (Solanum tuberosum L.) tubers. Journal of Postharvest Technology, 2(3), 152-168.

Chakraborty, C., Roychowdhury, R., Chakraborty, S., Chakravorty, P., \& Ghosh, D. (2017). A review on post-harvest profile of sweet potato. International Journal of Current Microbiology and Applied Sciences, 6(5), 1894-1903. https://doi.org/10.20546/ijcmas
Chattopadhyay, A., Chakraborty, I., Kumar, P. R., Nanda, M. K., \& Sen, H. (2006). Uncontrolled storage behaviour of sweet potato (Ipomoea batatas L. Lam). Journal of Food Science and Technology-Mysore, 43(1), 41-45.

Cooley, J., Kushman, L., \& Smart, H. (1954). Effect of temperature and duration of storage on quality of stored sweetpotatoes. Economic Botany, 8(1), 21-28. https://doi.org/10.1007/BF02898877

Crissman, C., Anderson, P., Fuglie, K., Kapinga, R., Lemaga, B., Devaux, A., ... Bussink, C. (2007). Trends in the potato and sweetpotato sectors in sub-Saharan Africa and their contribution to the Millennium Development Goals. In R. E. Kapinga, R. Kingamkono, M. Msabaha, J. Ndunguru, B. Lemaga \& G. Tusiime (Eds.), Tropical root and tuber crops: Opportunities for poverty alleviation and sustainable livelihoods in developing countries: Proceedings of the thirteenth triennial symposium of the international society for tropical root crops (iSTRC) (pp. 9-19). Arusha, Tanzania: International Society for Tropical Root Crops.

Degras, L. (2003). Sweet potato: The tropical agriculturalist. Lima, Peru: Macmillian, Technical Center for Agricultural and Rural Co-operation (ACP-EU).

Edison, S., Hedge, V., Makeshkumar, T., Srinivas, T., Suja, G., \& Padmaja, G. (2009). Sweetpotato in the Indian Sub-Continent. In G. Loebenstein \& G. Thottappilly (Eds.), The sweetpotato (pp. 391414). Dordrecht: Springer Science \& Business Media. https://doi. org/10.1007/978-1-4020-9475-0

Edmunds, B. A., Boyette, M. D., Clark, C. A., Ferrin, D. M., Smith, T. P., \& Holmes, G. J. (2008). Postharvest handling of sweetpotatoes. Albemarle, NC: North Carolina State University Cooperative Extension Service.

Essilfie, E. (2015). Yield and Storability of Sweetpotato (Ipomoea Batatas (L.) Lam) As influenced by Chicken Manure and Inorganic Fertilizer. PhD. Thesis, University of Ghana.

Essilfie, E., Ofosu-Anim, J., Dapaah, K., Norman, J., \& Blay, E. (2015). Growth and Yield of Sweetpotato (Ipomoea batatas [L.] Lam) as influenced by chicken manure and inorganic fertilizers. American Journal of Experimental Agriculture, 11(1), 1-20. https://doi.org/10.9734/ ajea/2016/22440

Eze, S., \& Orkwo, G. (2010). Studies on effects of mineral fertilizer, organic manure and cultivar on the yield and storability of Yam (Dioscorea rotundata Poir). African Journal of Food, Agriculture, Nutrition and Development, 10(6), 2755-2771.

Ezell, B. D., \& Wilcox, M. S. (1952). Influence of storage temperature on carotene, total carotenoids and ascorbic acid content of sweetpotatoes. Plant Physiology, 27(1), 81. https://doi.org/10.1104/ pp.27.1.81

Ganesan, M., Balasubramanian, K., \& Bhavani, R. (2013). Effect of water on the shelf-life of brinjal in zero-energy cool chamber. Journal of the Indian Institute of Science, 84(3 and 4), 107.

Gibberson, D. I., Joshua, O.-S., Ato, B.-P., Justice, O., \& Paul, A. A. (2016). The effect of deficit irrigation and manure on soil properties, growth and yield of orange fleshed sweet potato [Ipomea batatas Lam]. Scholars Journal of Agriculture and Veterinary Sciences, 3(7), 463-473. https://doi.org/10.21276/sjavs.2016.3.7.4

Hailu, S., Seyoum, T., \& Dechassa, N. (2008). Effect of combined application of organic $P$ and inorganic $N$ fertilizers on post harvest quality of carrot. African Journal of Biotechnology, 7(13), 2187-2196. https://doi. org/10.5897/AJB08.061

Hayma, J. (2003). The storage of tropical agricultural products (4th edn). Wageningen, the Netherlands: Agromisa Foundation, Wageningen.

Hirose, S., Data, E., \& Quevedo, M. (1984). Changes in respiration and ethylene production in cassava roots in relation to postharvest deterioration.

Jenkins, P. D. (1982). Losses in sweet potatoes (Ipomoea batatas) stored under traditional conditions in Bangladesh. Journal of Tropical Science, 24(1), 17-28. 
Kapinga, R., Jeremiah, S., Rwiza, E., \& Rees, D. (2003). Farmer criteria for selection of sweet potato varieties. Sweet potato postharvest assessment: experiences from East Africa. Chapman: Sweet potato postharvest assessment: Experiences from East Africa, 9-21.

Karuri, E. G., \& Hagenimana, V. (1995). Use of ambient conditions and sawdust in storage of sweetpotato (Ipomoea batatas L.) roots in Kenya. Zimbabwe Journal of Agricultural Research, 33, 83-91.

Kolbe, H., Müller, K., Olteanu, G., \& Gorea, T. (1995). Effects of nitrogen, phosphorus and potassium fertilizer treatments on weight loss and changes in chemical composition of potato tubers stored at $4^{\circ} \mathrm{C}$. Potato Research, 38(1), 97-107. https://doi.org/10.1007/BF02358074

Kwach, J. K., Odhiambo, G., Dida, M., \& Gichuki, S. (2010). Participatory consumer evaluation of twelve sweetpotato varieties in Kenya. African Journal of Biotechnology, 9(11), 1600-1609. https://doi. org/10.5897/AJB

Lal Basediya, A., Samuel, D., \& Beera, V. (2013). Evaporative cooling system for storage of fruits and vegetables-a review. Journal of Food Science and Technology, 50(3), 429-442. https://doi.org/10.1007/ s13197-011-0311-6

Lewthwaite, S. L., Sutton, K. H., \& Triggs, C. M. (1997). Free sugar composition of sweetpotato cultivars after storage. New Zealand Journal of Crop and Horticultural Science, 25, 33-41. https://doi.org/10.1080 /01140671.1997.9513984

Liberty, J., Okonkwo, W., \& Echiegu, S. (2013). Evaporative cooling: A postharvest Technology for fruits and vegetables preservation. International Journal of Scientific \& Engineering Research, 4(8), 2257-2266.

Liberty, J., Ugwuisuwu, B., Pukuma, S., \& Odo, C. (2013). Principles and application of Evaporative cooling System for fruits and vegetables preservation. International Journal of Current Engineering and Technology, 3(3), 1000-1006.

Mittal, A., Kataria, T., Das, G. K., \& Chatterjee, S. G. (2006). Evaporative cooling of water in a small vessel under varying ambient humidity. International Journal of Green Energy, 3(4), 347-368. https://doi. org/10.1080/01971520600704654

Muzhingi, T., Yeum, K. J., Qin, J., \& Tang, G. (2008). Determination of carotenoids in yellow maize, the effects of saponification and food preparations. International Journal for Vitamin and Nutrition Research 78(3), 112-120. https://doi.org/10.1024/0300-9831.78.3.112

Nedunchezhiyan, M., \& Ray, R. C. (2010). Sweet potato growth, development, production and utilization: Overview. In R. C. Ray, \& K. I. Tomlins (Eds.), Sweet potato: Post harvest aspects in food (pp. 2-26). New York: Nova Science Publishers Inc.

Olosunde, W. A., Igbeka, J., \& Olurin, T. O. (2009). Performance evaluation of absorbent materials in evaporative cooling system for the storage of fruits and vegetables. International Journal of Food Engineering, 5(3), 1-15. https://doi.org/10.2202/1556-3758.1376

Ravi, V., Aked, J., \& Balagopalan, C. (1996). Review on tropical root and tuber crops I. Storage methods and quality changes. Critical Reviews in Food Science and Nutrition, 36(7), 661-709. https://doi org/10.1080/10408399609527744

Ray, R. C., Ravi, V., Hegde, V., Rao, K. R., \& Tomlins, K. I. (2010). Post harvest handling, storage methods, pest and diseases of sweet potato. In R. C. Ray \& K. I. Tomlins (Eds.), Sweet potato: Post harvest aspects in food, feed and industry (pp. 27-57). New York: Nova Science Publishers, Inc.

Rees, D., van Oirschot, Q., Amour, R., Rwiza, E., Kapinga, R., \& Carey, T. (2003). Cultivar variation in keeping quality of sweetpotatoes. Postharvest Biology and Technology, 28(2), 313-325. https://doi. org/10.1016/S0925-5214(02)00180-1

Riso, P., \& Porrini, M. (1997). Determination of carotenoids in vegetable foods and plasma. International Journal for Vitamin and Nutrition Research. Internationale Zeitschrift fur Vitamin-und Ernahrungsforschung. Journal International de Vitaminologie et de Nutrition, 67(1), 47-54.

Roy, S., \& Khurdiya, D. (1983). Zero energy cool chamber for storage of horticultural produce. New Delhi, India: Science in Service of Agriculture. Indian Agricultural Research Institute.

Sowley, E., Neindow, M., \& Abubakari, A. (2015). Effect of poultry manure and NPK on yield and storability of orange-and white-fleshed sweet potato [Ipomoea batatas (L.) Lam]. ISABB Journal of Food and Agricultural Sciences, 5(1), 1-6.

Tomlins, K., Ngendello, T., Rwiza, E., Nyango, A., Kapinga, R., Rees, D., ... Jolliffe, F. (2004). The use of sensory evaluation and consumer preference for the selection of sweetpotato cultivars in East Africa. Journal of the Science of Food and Agriculture, 84, 791-799. https:// doi.org/10.1002/jsfa.1712

Tumwegamire, S., Mwanga, R. O. M., Andrade, M., Low, J. W., Ssemakula, G. N., Laurie, S., ... Gruneberg, W. J. (2014). Orange-fleshed sweetpotato for Africa. Catalogue 2014 (2nd edn, pp. 74). Lima, Peru: International Potato Center (CIP).

Van Oirschot, Q., Ngendello, T., Rwiza, E., Amour, R., Tomlins, K., Rees, D., \& Westby, A. (2007). The potential for storage of fresh sweetpotato under tropical conditions: Evaluation of physiological changes and quality aspects. In R. E. Kapinga, R. Kingamkono, M. Msabaha, J. Ndunguru, B. Lemaga \& G. Tusiime (Eds.), Tropical root and tuber crops: Opportunities for poverty alleviation and sustainable livelihoods in developing countries: Proceedings of the Thirteenth Triennial Symposium of the International Society for Tropical Root Crops (ISTRC), (pp. 423434). Arusha, Tanzania: International Society for Tropical Root Crops.

Wang, Z. H., Li, S. X., \& Malhi, S. (2008). Effects of fertilization and other agronomic measures on nutritional quality of crops. Journal of the Science of Food and Agriculture, 88(1), 7-23. https://doi.org/10.1002/ (ISSN)1097-0010

Weston, L., \& Barth, M. (1997). Preharvest factors affecting postharvest quality of vegetables. HortScience, 32(5), 812-816.

Woolfe, J. A. (1992). Sweet potato: An untapped food resource. Cambridge, UK: Cambridge University Press.

How to cite this article: Atuna RA, Aduguba WO, Alhassan A-R, et al. Postharvest quality of two orange-fleshed sweet potato [Ipomoea batatas (L) Lam] cultivars as influenced by organic soil amendment treatments. Food Sci Nutr. 2018;6:1545-1554. https://doi.org/10.1002/fsn3.700 